\title{
PROPOZYCJE AKTUALNYCH TEMATÓW DLA DYDAKTYKI PRZYSZŁYCH KADR MENEDŻERSKICH W ZAKRESIE ETYKI BIZNESU
}

\section{WPROWADZENIE}

Od wielu lat w literaturze dotyczącej zagadnień gospodarczych i biznesowych dostrzegamy postulaty powrotu do humanistyki w podejściu do gospodarki i zarządzania. Oddzielną publikację temu zagadnieniu poświęciła Martha C. Nussbaum: Nie dla zysku. Dlaczego demokracja potrzebuje humanistów ${ }^{1}$. Namysł nad koniecznościa rozwijania refleksji nad gospodarką i naukami o zarządzaniu z perspektywy humanistycznej, a przede wszystkim wzmocnienia głosu sądu etycznego znajdujemy m.in. u takich współczesnych autorów, jak: Tomáš Sedláček w Ekonomii dobra $i$ zła ${ }^{2}$, Michael Sandel w książkach Sprawiedliwośćc ${ }^{3}$ oraz Czego nie można kupić za pieniadze $e^{4}$, Gilbert Rist w Urojenia ekonomii ${ }^{5}$, Paul H. Dembinski w Finanse po zawale ${ }^{6}$ lub wraz z Simona Berettą w książce Kryzys ekonomiczny i kryzys wartości ${ }^{7}$, czy wreszcie papież Franciszek w encyklice Laudato $s i^{8}$. W badaniach polskich naukowców rozwijane jest również zagadnienie konieczności wzmocnienia pespektywy humanistycznej w naukach o zarządzaniu. Jako przykład można podać badania nad zarządzaniem humanistycznym prowadzone przez Monikę Kosterę. Odrębną dziedziną dynamicznie rozwijana na świecie i w Polsce jest etyka biznesu.

Niniejszy artykuł stanowi próbę zaproponowania włączenia wybranych zagadnień do programów dydaktycznych na kursach przygotowujących przyszła kadrę zarządzającą. W rozważaniach nad koniecznością i potrzebą wzmocnienia wątku humanistycznego $\mathrm{w}$ dydaktyce $\mathrm{w}$ zakresie nauk o zarządzaniu zasadne wydaje się uchwycenie perspektywy myślenia zarówno teoretyczne-

\footnotetext{
${ }^{1}$ M. C. Nussbaum, Nie dla zysku. Dlaczego demokracja potrzebuje humanistów, Fundacja Kultura Liberalna, Warszawa 2016.

${ }^{2}$ T. Sedláček, Ekonomii dobra $i$ zła. W poszukiwaniu istoty ekonomii od Gilgamesza do Wall Street, Studio EMKA, Warszawa 2012.

${ }^{3}$ M. Sandel, Sprawiedliwość. Jak postepować stusznie?, Kurhaus, Warszawa 2013.

${ }^{4} \mathrm{M}$. Sandel, Czego nie można kupić za pieniadze. Moralne granice rynku, Kurhaus, Warszawa 2012 .

${ }^{5}$ G. Rist, Urojenia ekonomii, Instytut Wydawniczy Książka i Prasa, Warszawa 2015.

${ }^{6}$ P. H. Dembinski, Finanse po zawale. Od euforii finansowej do gospodarczego ładu, Studio EMKA, Warszawa 2012.

7 S. Beretta, Kryzys ekonomiczny i kryzys wartości, Wydawnictwo M, Kraków 2014.

${ }^{8}$ Encyklika Laudato si Ojca Świętego Franciszka poświęcona trosce o wspólny dom, Kraków 2015.
} 
go (rozumianej tutaj jako wyzwania dla dydaktyki w kontekście wyjaśniania między innymi globalnych zjawisk gospodarczych czy relacji na linii społeczeństwo-jednostka), jak i perspektywy praktycznej, która w tym artykule utożsamiana jest z opisem między innymi praktyk i zachowań aktorów biznesowych przejawiających się w wysiłkach na rzecz budowania etycznej kultury korporacyjnej. Niniejszy artykuł nie ma na ambicji kompleksowego omówienia wyróżnionych sposobów myślenia. Celem krótkiego rysu zagadnień merytorycznych podejmowanych w ramach każdego z dwóch poziomów jest wskazanie tematów z obszaru humanistyki, w szczególności etyki biznesu, oraz gospodarki, które mogą być częścią programu dydaktycznego w ramach takich przedmiotów, jak etyka biznesu, społeczna odpowiedzialność przedsiębiorstw czy zrównoważony rozwój.

Trudność, jaka pojawia się w dydaktyce podczas łączenia zagadnień z dziedzin zarządzania i humanistyki, wiąże się z tym, co Przemysław Rotengruber określa mianem waloru aplikacyjnego. Rotengruber problem ten przedstawia na przykładzie etyk stosowanych. Wyjaśnia, że przedstawiciele etyk stosowanych dążą do sprawdzenia swoich sądów dotyczących gospodarczego dobra i zła przy pomocy tych, do których się zwracaja. Jak twierdzi, etyki stosowane nie moga poprzestać jedynie na kryterium miarodajności sądów, lecz powinny pójść o krok dalej w stronę sprawdzania ich walorów aplikacyjnych. Zadaniem etyki stosowanej - w niniejszym artykule etyki biznesu - jest możliwość zastosowania w procesie tworzenia ładu zbiorowego. Oznacza to korespondowanie z zachowaniem zwykłych ludzi oraz wsparcie w korekcie ich zachowań. Aby to zadanie mogło zostać wykonane, konieczna jest wiedza o środowisku, do którego zwraca się etyk biznesu9 ${ }^{9}$.

Dlatego druga część artykułu stanowi przegląd wybranych badań związanych z etyką w działalności gospodarczej, które pozwola na wskazanie kluczowych nieetycznych praktyk na poziomie przedsiębiorstw oraz działań wdrażanych przez zarządy firm, pozwalajacych na minimalizowanie możliwości powstawania tego typu zachowań. Wnioski z przeglądu badań stanowia zestaw propozycji zagadnień, jakie mogłyby stać się przedmiotem nauczania podczas programu studiów kształtujących kadry menedżerskie. Punktem odniesienia są właśnie badania, gdyż takie podejście pozwoli na wskazanie konkretnych problemów i sposobów myślenia, z jakimi spotkają się absolwenci między innymi nauk ekonomicznych i nauk o zarządzaniu podczas pracy zawodowej.

W pierwszej kolejności zostaną przedstawione założenia i nurty we współczesnych badaniach $\mathrm{w}$ zakresie zarządzania humanistycznego. Następnie zostaną omówione postulaty Marthy C. Nussbaum w zakresie wzmocnienia podejścia humanistycznego w edukacji, również tej ekonomicznej i biznesowej. Pozwoli to, również na podstawie wniosków z wybranych badań w zakresie etyki biznesu, zasugerować aktualne zagadnienia, jakie dydaktycy w szkołach ekonomicznych i biznesowych mogliby rozwijać w działalności badawczej i dydaktycznej.

9 P. Rotengruber, Etyka w gospodarce, w: Etyka, cz. 2: Filozoficzna etyka życia spetnionego, red. S. Janeczek, A. Starościc, Dydaktyka Filozofii 5, Wyd. KUL, Lublin 2016, s. 141-146. 


\section{ZARZĄDZANIE HUMANISTYCZNE - WPROWADZENIE}

Jak przekonuja Monika Kostera i Jerzy Kociatkiewicz, propagatorzy nurtu humanistycznego w zarządzaniu, elementy etyczne i społeczne były obecne od początku powstania nauk o zarządzaniu. Już prekursorzy tej nauki, do których możemy zaliczyć Fredericka Taylora czy Maxa Webera, wskazywali na jej interdyscyplinarność, łącząc wiedzę społeczną z ekonomiczną. Ta druga w naukach o zarządzaniu zaczęła dominować od lat pięćdziesiątych XX w. Powrót do perspektywy humanistycznej to lata dziewięćdziesiąte XX w. Różnicę między punktem widzenia ekonomicznym a humanistycznym można wyjaśnić z perspektywy ich celu. Nurt ekonomiczny zorientowany jest na poprawę wskaźników efektywnościowych funkcjonowania organizacji, natomiast celem nurtu humanistycznego jest pomoc człowiekowi w poprawie jego losu ${ }^{10}$.

Zaleta podejścia humanistycznego, na którą wskazują Kostera i Kociatkiewicz, jest badanie konkretnych zdarzeń będących konsekwencją działań człowieka, a nie abstrakcyjnych zjawisk i prawidłowości. A o ten konkret dla etyki biznesu $\mathrm{w}$ kontekście nauk o zarządzaniu dopomina się wspomniany już wcześniej Rotengruber. Podejście humanistyczne dociera do tego konkretu przez zrozumienie otaczającego nas świata. A to, jak przekonują Kociatkiewicz i Kostera, pozwala na identyfikację problemów dotykających współczesne organizacje i ich uczestników. Dodają również, że dyscyplina naukowa, jaka jest zarządzanie humanistyczne, pozwala na budowanie sensu za pomoca wyjaśniania procesów historycznych, a także na znajdowanie rozwiązań dla zidentyfikowanych problemów. Akcentują również, co jest istotne z punktu widzenia tematu niniejszego artykułu, znaczenie kształcenia studentów w nurcie zarządzania humanistycznego. Rozumieją edukację uniwersytecka jako proces całościowy, majaccy znaczenie i skutki społeczne, a nie tylko indywidualne. Przekonuja, że celem kształcenia studentów zarządzania nie może być jedynie przygotowanie do zawodu kierownika, ale także rozwój świadomego uczestnictwa w zmieniającej się rzeczywistości społecznej ${ }^{11}$.

Kostera i Kociatkiewicz w artykule Art and organizing: lessons for organization theory from the humanities podkreślają znaczenie perspektywy człowieka w teorii organizacji, wskazując na ważną rolę relacji, uczuć i estetyki $\mathrm{w}$ procesie organizowania ${ }^{12}$. Do tego zagadnienia wracają w opublikowanym w roku 2013 artykule Zarzqdzanie humanistyczne. Zarys programu, w którym za Gibsonem Burrellem oraz Garethem Morganem ${ }^{13}$ wyróżniają cztery podstawowe paradygmaty w naukach społecznych: funkcjonalistyczny, imperatywny, radykalny humanistyczny i radykalny strukturalistyczny.

10 Por. J. Kociatkiewicz, M. Kostera, Zarzadzanie humanistyczne. Zarys programu, „Problemy Zarządzania” 11, 2013, nr 4(44), s. 13.

11 Ibidem, s. 17.

12 J. Kociatkiewicz, M. Kostera, Art and organizing: lessons for organization theory from the humanities, „Master of Business Administration” 50(3), 2001, s. 24-27.

${ }^{13}$ Por. G. Burrell, G. Morgan, Sociological Paradigms and Organizational Analysis, Heinemman, London 1979. 
Każdy z omawianych paradygmatów wskazuje na konieczność analizowania relacji i zależności między społeczeństwem, organizacją a jednostka, chociaż czynią to z różnych perspektyw oraz w różnym celu. Na przykład szkoła badawcza w nurcie paradygmatu funkcjonalistycznego głosi, że społeczeństwo istnieje obiektywnie, jako byt konkretny i realny. Przedstawiciele funkcjonalizmu poszukują ukrytych, ale realnie istniejących motywów i przyczyn zjawisk społecznych, ważnych z punktu widzenia fundamentalnych konsekwencji ogólnospołecznych. Zgodnie z tym paradygmatem nauka powinna dążyć do obiektywizmu i wolności od wartościowania. Szkoła interpretatywana zakłada względność rzeczywistości społecznej i stawia sobie za zadanie zrozumienie i interpretowanie zjawisk społecznych. W nurcie radykalnego humanizmu istnieje przekonanie o braku absolutyzmu i obiektywizmu społecznego, a celem jest oferowanie ludziom pomocy, jak żyć lepiej, jak być szczęśliwym i jak dostosować struktury społeczne do ludzkich potrzeb. Ambicją jest uzyskanie praktycznego efektu. Natomiast przedstawiciele radykalnego strukturalizmu zakładają istnienie konkretnej rzeczywistości społecznej. Swoją rolę widza w przełamywaniu opresyjnego charakteru zjawisk społecznych. Stawiaja sobie za zadanie identyfikację wzorów i mechanizmów w celu wskazania dróg do osiagnięcia pożądanych celów, np. postępu lub wyzwolenia ${ }^{14}$. Do tego właśnie nurtu możemy zaliczyć wpływową współczesną filozof Marthę C. Nussbaum, chociaż należy wyjaśnić, że ona sama tak siebie nie klasyfikuje.

\section{INSPIRACJE MARTHY C. NUSSBAUM DLA DYDAKTYKI W ZAKRESIE ZARZĄDZANIA HUMANISTYCZNEGO}

Martha C. Nussbaum w książce Nie dla zysku. Dlaczego demokracja potrzebuje humanistów stawia tezę, że pedagodzy koncentrujący się na wzroście gospodarczym nie ograniczają się do ignorowania nauk humanistycznych. Przekonuje, że oni się ich boja, a to dlatego że „pielęgnowanie i rozwijanie zdolności wzajemnego zrozumienia jest szczególnie niebezpiecznym wrogiem tępoty, podczas gdy moralna tępota to warunek konieczny wprowadzenia programów rozwoju gospodarczego, które ignorują kwestie nierówności”15. Chociaż Nussbaum swoje badania prowadziła przede wszystkim w Stanach Zjednoczonych oraz Indiach, to wnioski z nich płynące ekstrapoluje na większość systemów edukacji ekonomicznej. Jest przekonana, że edukacja nakierowana na wzrost gospodarczy ma wszędzie podobne cechy. I to właśnie doktryna czy wręcz „terror” pojęcia wzrostu gospodarczego jest dla autorki przyczyną wielu patologicznych zjawisk społecznych. Jej zdaniem niepohamowana pogoń za wzrostem nie sprzyja pogłębionej refleksji nad problemami redystrybucji czy nierówności społecznych. Zatem na poziomie społecznym prowadzi do wielu patologicznych zjawisk, z których najgroźniejszym, zdaniem wielu badaczy

14 J. Kociatkiewicz, M. Kostera, Zarzqdzanie humanistyczne..., s. 11-12.

15 M. C. Nussbaum, op. cit., s. 40. 
(m.in. Thomasa Piketty), jest pogłębiająca się nierównośćc ${ }^{16}$. Dogmat konieczności ciagłego wzrostu przekłada się również na kształtowanie postaw na poziomie jednostek, których wynikiem jest wiele niemoralnych zachowań pojedynczych uczestników życia gospodarczego. Na poziomie jednostki kult kategorii wzrostu wpływa na rozwój postawy chciwości, co skłania np. pracowników przedsiębiorstw do nieetycznych uczynków.

Wpływ idei i zjawisk społecznych, takich jak paradygmat wzrostu oraz przekonanie, że zmiana na poziomie społecznym jest możliwa przez zmianę na poziomie jednostek, jest istotny z punktu widzenia celów stawianych w dydaktyce, również tej w zakresie zarządzania. Martha C. Nussbaum, przedstawiając tę zależność, podaje przykład Mahatmy Gandhiego, który - jej zdaniem rozumiał doskonale, że polityczna walka o wolność i równość musi być przede wszystkim walką wewnątrz każdego człowieka, podczas której zrozumienie i szacunek ścierają się ze strachem i chciwością ${ }^{17}$. Za pogłębianiem analiz nad wpływem perspektywy zewnętrznej przemawiają przywoływane przez autorkę liczne wyniki badań psychologii eksperymentalnej potwierdzające tezę, że ludzie o podobnych skłonnościach zachowują się gorzej, kiedy znajdują się w zaplanowanej w szczególny sposób sytuacji1 ${ }^{18}$. Ci sami ludzie, którzy mogliby postapić właściwie w sytuacji innego rodzaju, postępowali niewłaściwie w określonych okolicznościach. Jako przykład Nussbaum przywołuje wyniki jednego z badań, na podstawie którego wysnuto wniosek, że jeśli chociażby jedna osoba w grupie wyraża zdanie odmienne od pozostałych, inni członkowie grupy zdobywają się na wyrażanie niezależnych sądów. Inną sytuacja, w której ludzie nie postępują właściwie, jest stworzenie takich warunków, w których wywołuje się u ludzi przekonanie, że nie odpowiadają za swoje własne decyzje. Jeśli odpowiedzialność bierze na siebie osoba obdarzona władza, prowadzi to do podejmowania decyzji nieodpowiedzialnych. Badaczka zwraca uwagę na fakt, że z pozoru przyzwoici i dobrze wychowani ludzie gotowi sa do stygmatyzujących i poniżajaccych zachowań, jeśli tylko okoliczności zostana w odpowiedni sposób zaaranżowane, tzn. ich samych ustawi się w dominującej roli, a innych ludzi przedstawi się jako gorszych ${ }^{19}$.

$\mathrm{Na}$ podstawie powyższych przykładów należy zwrócić uwagę na okoliczności jako wpływową determinantę zachowań etycznych. Nussbaum wymienia trzy rodzaje sytuacji, które znacząco oddziałują na decyzje i zachowania etyczne. Po pierwsze, ludzie zachowują się niewłaściwie, kiedy nie ponosza osobistej odpowiedzialności. Z brakiem osobistej odpowiedzialności łączy się poczucie anonimowości, kiedy jednostki nie sa pociagane do indywidualnej odpowiedzialności, a traktowane sa jako bezimienna masa. Po drugie, ludzie za-

${ }^{16}$ Por. T. Piketty, Kapitat XXI wieku, tłum. A. Bilik, Wyd. Krytyki Politycznej, Warszawa 2015.

${ }^{17}$ M. C. Nussbaum, op. cit., s. 47.

${ }^{18}$ To zjawisko analizuje Nussbaum, przywołując doświadczenia prowadzone przez takich naukowców, jak Stanley Milgram, Solomon Asch czy Philipa Zimbardo, który to przeprowadził najsłynniejszy eksperyment, aranżując więzienie i przydzielając studentom role strażników oraz więźniów. Eksperyment, który z powodu brutalnych zachowań odtwórców roli więźniów musiał zostać wcześniej, niż planowano, przerwany.

${ }^{19}$ M. C. Nussbaum, op. cit., s. 60. 
chowują się niewłaściwie, kiedy nikt nie zgłasza sprzeciwu, nawet jeśli decyzja czy osąd są błędne. Po trzecie, ludzie zachowują się niewłaściwie, gdy inne osoby, nad którymi mają władzę, są odczłowieczane i odindywidualizowane ${ }^{20}$.

Nussabum w swojej książce przedstawia kilka wskazówek dla szkół, dzięki którym moga skuteczniej kształtować obywateli zdolnych działać na rzecz innych w rozwijających się demokracjach. Wydaje się, że te podpowiedzi również można odnieść do nauczania studentów na kierunkach ekonomicznych i biznesowych, i dzięki temu zwrócić uwagę na zagadnienia etyczne oraz związane ze społeczna odpowiedzialnościa przedsiębiorstw. Nussbaum jest przekonana, że szkoła (warto dodać, że również szkoła wyższa) może wzmacniać lub osłabiać pozytywne, a także negatywne oddziaływanie rodzinne, rówieśnicze i środowiska pracy. Te wskazówki zawarła w siedmiu postulatach. Postulat pierwszy to podejmowanie wysiłków w zakresie rozwijania zdolności uczniów do postrzegania świata z punktu widzenia innych ludzi, szczególnie tych, których społeczeństwo przedstawia jako gorszych. Drugi nawołuje do uczenia postawy wobec ludzkiej słabości i bezbronności, tzn. że słabość nie musi być powodem do wstydu, a potrzeba wsparcia ze strony innych nie jest niemęska. Trzecim postulatem jest zadbanie o wykształcenie zdolności do prawdziwej troski o innych. Czwarty związany jest $\mathrm{z}$ nauczaniem szacunku do mniejszości. Piąty, który jest związany z czwartym, dotyczy dostarczania rzeczywistych i prawdziwych informacji o innych grupach, tak aby zwalczać stereotypy i towarzyszące im częstokroć poczucie wstrętu. Szósty nawołuje do promowania odpowiedzialności przez traktowania każdego ucznia jako odpowiedzialnej, aktywnej jednostki. Siódmy postulat jest apelem o intensywne wspieranie myślenia krytycznego, umiejętności i odwagi, jakich wymaga wyrażenie sprzeciwu wobec dominujących opinii ${ }^{21}$.

Nussbaum swoje zasady odnosi również do sytuacji biznesowej, a dokładniej - działalności przedsiębiorstw. Zdaje sobie sprawę, że na tym polu głównym celem jest wynik ekonomiczny. Nawet jeśli tak jest, to - jej zdaniem - najważniejsi przedstawiciele zarządów są świadomi wagi kultury korporacyjnej, w której pozwala się jednostkom działać, zrzuca się na nich odpowiedzialność przy jednoczesnym daniu możliwości wyrażania krytyki. Przekonuje, że największe bankructwa gospodarcze w Stanach Zjednoczonych takich firm, jak Enron czy WorldCom, miały swoje źródła w kulturze potakiwania, w której z lęku przed autorytetem i pod wpływem presji środowiska pracownicy nie wyrażali sądów krytycznych. Nussbaum wiąże prawo do wyrażania opinii z odpowiedzialnością. Przekonuje, że kładąc nacisk na wyrażanie opinii w procesie edukacji, promowana jest kultura odpowiedzialności. Jej zdaniem, jeśli ludzie biora odpowiedzialność za swoje idee, istnieje większa szansa, że wezmą też odpowiedzialność za swoje czyny. Dlatego, jak twierdzi, edukacja liberalna powinna przekazywać wartości sokratejskie. Przejawem tych wartości na poziomie edukacji wyższej powinno być myślenie krytyczne jako element sposobu nauczania. W praktyce oznacza to wymaganie od studentów badania i oce-

\footnotetext{
20 M. C. Nussbaum, op. cit., s. 62.

21 Ibidem, s. 63-64.
} 
niania dowodów, pisania prac o dobrze ustrukturyzowanej argumentacji oraz analizowania argumentów pochodzących z tekstów innych osób ${ }^{22}$.

We współczesnej dydaktyce humanistycznej w obszarze zarządzania dla Nussbaum istotne jest umiejscowienie zjawisk gospodarczych danego państwa na tle globalnym. Dopiero takie przedstawianie zagadnień gospodarczych prowadzi do odpowiedzi na pytanie o zakres odpowiedzialności graczy rynkowych. Podając przykład, Nussbaum pisze, że nie zrozumiemy, skąd pochodzi zwykły napój, jeśli nie weźmiemy pod uwagę mieszkańców innych państw. Kiedy już to zrobimy, musimy zapytać o warunki pracy tych ludzi, ich wykształcenie i stosunki z pracodawcami. Zadawanie tego rodzaju pytań prowadzi nas dalej, do zastanowienia się nad naszymi zobowiązaniami wobec tych ludzi. Zdaniem amerykańskiej autorki bierzemy udział w tworzeniu warunków pracy, a przez to ich codziennego życia. W jakim stopniu mamy wpływ na te warunki i czy oraz co możemy zrobić, aby w razie konieczności domagać się zmian i poprawy warunków życia i pracy tych, którzy znajdują się w łańcuchu produkcji pijanego przez nas napoju? Stąd konieczność położenia nacisku w edukacji na wyjaśnienie, jak funkcjonuje globalna gospodarka, czy rolę zagranicznych inwestycji wielonarodowych korporacji ${ }^{23}$.

\section{AKTUALNE WĄTKI ETYKI BIZNESU PORUSZANE W BADANIACH}

Refleksje Nussbaum na temat źródeł i warunków przyczyniających się do nieetycznych zachowań w ograniczonym stopniu pokrywają się z obszarami analiz międzynarodowych organizacji zajmujących się badaniami w zakresie etyki biznesu. Co prawda temat warunków pracy w łańcuchu dostaw przebija się do dyskursu o etyce biznesu, głównie dzięki aktywnościom organizacji pozarządowych, jednakże w omawianych poniżej badaniach nie zostaje uznany za kluczowy.

Współczesne badania dotyczące etyki biznesu w centrum uwagi stawiaja zagadnienie korupcji, podejścia do zarządzania i doboru odpowiednich narządzi, które umożliwią budowanie etycznej kultury korporacyjnej. Natomiast główny nurt badań w zakresie etyki biznesu na poziomie organizacji koncentruje się na identyfikacji zagrożeń, jakie płyną z niemoralnych uczynków dla przedsiębiorstwa. Wyniki analiz pozwalają postawić tezę, że pomimo iż identyfikacja rodzajów ryzyka biznesowego jest podstawowym poziomem rozpatrywania problemu etyki biznesu, to takie podejście jest wciąż aktualne i potrzebne. Nie chodzi tutaj jedynie o charakter popełnianych nieetycznych uczynków, który ze względu chociażby na nowe formy korupcji się zmienia, ale również grupę wiekową sprawców. Jak wynika z Badania Nadużyć Gospodarczych EY „Ludzki instynkt czy logika maszyn - czemu ufasz bardziej w walce z korupcja i nadużyciami”, które zostało przeprowadzone w 41 krajach Europy, Bliskiego

\footnotetext{
22 Ibidem, s. 71-73.

23 Ibidem, s. 100.
} 
Wschodu oraz Afryki (w tym w Polsce), największej liczby nadużyć gospodarczych, szczególnie działając pod presja, dopuszczają się przedstawiciele tak zwanego pokolenia Y, czyli osoby w wieku 25-34 lata. Wielu z nich to niedawni absolwenci szkół ekonomicznych i biznesowych. Aż jeden na czterech ankietowanych w tym wieku mógłby usprawiedliwić wręczenie gotówki, gdyby od tego zależał wynik firmy. Dla porównania takiej odpowiedzi udzielił zaledwie 1 na 10 badanych powyżej 45 roku życia. Pokolenie Y także zdecydowanie częściej niż inne generacje posądziłoby swoich kolegów z pracy o nieetyczne postępowanie w celu osiagnięcia korzyści. Ponadto $2 / 3$ ankietowanych bez trudu uwierzyłoby, że zarząd podją działania niezgodne ze standardami moralnymi dla dobra firmy ${ }^{24}$.

Co prawda w Polsce maleje odsetek osób postrzegających korupcję jako poważny problem biznesowy: w 2013 r. uważało tak 59\%, w 2015 - 43\%, w 2017 zaś takiego zdania jest $38 \%$ ankietowanych, jednakże problem nadal pozostał. Presja osiagania wzrostu wywierana na pracowników sprawia, że są oni skłonni do nieetycznych działań. Dla osiagnięcia celów osobistych lub firmy wciąż co dziesiąty byłby skłonny oferować gotówkę. W Europie Wschodniej takiej odpowiedzi udzieliło aż 19\% ankietowanych. W Polsce 14\% respondentów zaksięgowałoby przychody wcześniej, żeby osiagnaćc zakładane cele biznesowe, a 9\% przekazałoby fałszywe informacje zarządowi, by zapewnić sobie awans lub podwyżkę ${ }^{25}$. Z drugiej strony autorzy badania wskazują, że przyjęte w firmach standardy etyczne maja znaczenie dla pracowników w Polsce. W wątpliwej moralnie sytuacji $13 \%$ zrezygnowałaby, a $48 \%$ rozważałoby odejście z pracy ${ }^{26}$.

Odejście od perspektywy typowo zarządczej oraz koncentracji na zagadnieniach korupcji, przestrzegania praw człowieka oraz podstawowych praw pracowniczych w badaniach na temat etyki biznesu prezentuje inicjatywa Global Business Ethical Survey ${ }^{27}$. Autorzy badania zwracaja uwagę na konieczność włączenia do głównego nurtu etyki biznesu zagadnień z zakresu etyki zasad. Zadają też pytania o charakterze kulturowym, chcąc dowiedzieć się, jakie zachowania wpływają na etyczne bądź nieetyczne postępowanie w miejscu pracy.

Badanie Global Business Ethical Survey przeprowadzone przez Ethical Reseach Center (ERC; będące częścią organizacji Ethics \& Compliance Initiative) w roku 2015, a którego wyniki zostały opublikowane w 2016 , to jedno z najstarszych przedsięwzięć badawczych w zakresie etyki biznesu, a swoją pierwszą odsłonę miało w 1994 r. Omawiana edycja badania z 2015 r. została przeprowadzona metodą CAWI ${ }^{28}$ (Computer Assisted Web Interviews - wy-

${ }^{24}$ Badanie prowadzone było od listopada 2016 do stycznia 2017 r. w 41 krajach regionu Europy, Bliskiego Wschodu oraz Afryki (EMEIA), w tym z Polski. Wzięło w nim udział ponad 4100 respondentów z kadry zarządzającej i pracowników.

${ }^{25}$ Raport EY: Co czwarty polski pracownik jest gotów postepować nieetycznie dla awansu lub podwyżki. Większość to przedstawiciele pokolenia Y, źródło: www.blog.ey.pl [dostęp: 22.06.2017].

${ }^{26}$ Ibidem.

${ }^{27}$ Global Business Ethics Survey. Measuring Risks and Promoting Workplace Integrity, Ethics Research Center, Arlington (USA) 2016.

${ }^{28}$ Technika badań CAWI to wywiad przeprowadzony przez kwestionariusz czy też ankietę wypełniane online. 
wiadów wspomaganych komputerowo), a wzięło w niej udział ponad 13000 osób. Po ponad 1000 respondentów, którzy byli pracownikami zatrudnionymi przez różnego rodzaju przedsiębiorstwa w 13 krajach (Indie, Stany Zjednoczone, Wielka Brytania, Brazylia, Meksyk, Japonia, Włochy, Francja, Chiny, Niemcy, Hiszpania, Korea Południowa oraz Rosja ${ }^{29}$.

Zagadnienie kultury w przestrzeganiu zasad jest - zdaniem autorów badania - kluczowe. Wskaźnikiem, który pozwala na określenie, w jakim stopniu realne jest wystapienie nieetycznych zachowań w organizacji, jest podejście do zasad i standardów. W tych organizacjach, w których występuje presja na łamanie standardów etycznych, najczęściej dochodzi do nieetycznych zachowań. Autorzy badania presję tę określaja jako nacisk na pracowników, aby naruszali zasady i normy: 73\% badanych, którzy odczuwali taką presję w miejscu pracy, przyznało również, że było świadkiem nieetycznych zachowań w swojej organizacji ${ }^{30}$. Zatem konieczne jest budowanie wśród obecnych i przyszłych menedżerów takich kompetencji, które pozwolą im zwracać uwagę na czynnik nacisku na nieetyczne zachowania, oraz poszukiwanie ich źródeł, które moga wynikać z niewłaściwie określonych celów lub niedopasowanego do organizacji ładu korporacyjnego.

W raporcie z badania zauważono, że pomimo różnic ekonomicznych czy kulturowych analizowanych krajów można wyróżnić kilka powtarzających się zachowań nieetycznych. Dla przykładu w 11 z 13 badanych krajów kłamstwo, szykanowanie i zastraszanie badani zakwalifikowali jako trzy najczęstsze przypadki nieetycznych zachowań ${ }^{31}$. Autorzy badania zwracają uwagę na fakt, że incydentalne przypadki nieetycznych zachowań są mniej groźne niż długotrwałe, wręcz systemowe łamanie zasad. Podkreślają że większe negatywne skutki powoduje nieetyczne zachowanie menedżerów niż pracowników szeregowych. Do najczęstszych przypadków nieetycznych zachowań, jakich dopuszcza się kadra zarządzająca wyższego szczebla, odpowiadający zaliczyli: nadużycia wobec pracowników (w tym ich zastraszanie), przyjmowanie łapówek lub nieodpowiednich prezentów, doprowadzanie do konfliktu interesów (czyli sytuacji, w której interes własny lub innych powiązanych osób stawia się ponad interes organizacji), stosowanie praktyk zaburzających konkurencyjność, ukrywanie nieprawidłowości podczas wewnętrznych i zewnętrznych inspekcji, naruszanie praw człowieka, niewłaściwe zapisy w umowach oraz nieprzestrzeganie terminów płatności dostawcom, okłamywanie pracowników, dostawców i klientów ${ }^{32}$.

W raporcie z badań znajduje się również analiza problemu zgłaszania przez pracowników informacji o nieprawidłowościach. Zagadnienie sygnalistów jest dyskutowane w Polsce od wielu lat. Niektóre przedsiębiorstwa starają się wdrażać anonimowe i bezpieczne kanały zgłaszania o nadużyciach. Natomiast czynnikami wpływajacymi na brak rozwoju tego typu sposobów

\footnotetext{
${ }^{29}$ Szczegóły metodologii znajdują się raporcie Global Business Ethics Survey. Measuring Risks and Promoting Workplace Integrity, Ethics Research Center, Arlington (USA) 2016, s. 2.

${ }^{30}$ Global Business Ethics Survey..., s. 10.

${ }^{31}$ Ibidem, s. 11-12.

${ }^{32}$ Ibidem, s. 14.
} 
informowania o nieetycznych praktykach sa negatywne konotacje historyczne związane z instytucja donosiciela oraz współcześnie brak odpowiednich regulacji chroniących osoby zgłaszające nadużycia. Autorzy omawianego badania podkreślaja, że informacja o nieprawidłowości daje zarządzającym możliwość wdrożenia działań naprawczych. Z drugiej strony brak takiej informacji od osób, które są w jej posiadaniu, powoduje, że nieetyczne praktyki się zakorzeniaja i rozszerzaja $\mathrm{w}$ organizacji. Wnioski, jakie płyna $\mathrm{z}$ badania $\mathrm{w}$ tym zakresie, wskazuja, że wśród pracowników jest gotowość do informowania o nieetycznych zachowaniach. Natomiast w badaniach został ujawniony problem, jakim są działania odwetowe wobec zgłaszajacych. W 11 z 13 badanych krajów co najmniej jedna na trzy zgłaszające osoby doświadczyła działań odwetowych. I to właśnie strach przed działaniami odwetowymi jest główną przyczyną powstrzymania się od informowania o nadużyciu ${ }^{33}$.

$\mathrm{Z}$ punktu widzenia dydaktyki w zakresie etyki biznesu istotne jest nie tylko wskazywanie na wyzwania i dylematy etyczne, jakie pojawiają się w przestrzeni gospodarczej, lecz także podpowiadanie rozwiązań i analizowanie działań prowadzonych przez firmy. Przedsiębiorstwa za pomoca różnych przedsięwzięć, w tym wdrożenia odpowiedniego ładu korporacyjnego, dążą do stworzenia takich warunków prowadzenia działalności gospodarczej oraz stosunków pracy, które zminimalizują możliwość powstawania niepożądanych sytuacji. Organizacje międzynarodowe zajmujące się zagadnieniem etyki biznesu za pomoca prowadzonych badań sprawdzają również, jakie działania podejmuja przedsiębiorstwa, aby stymulować zachowania etyczne i minimalizować ryzyko pojawiania się zachowań nieetycznych. Jedną z takich instytucji jest londyńska organizacja działająca od 1986 r.: Institute of Business Ethics; w 2016 r. opublikowała ona raport „Corporate Ethics Policies and Programmes. 2016 UK and Continental Europe Survey"34. Jest to ósme z serii badań prowadzonych przez Instytut regularnie co trzy lata. Badanie zostało przeprowadzone, podobnie jak badanie Global Business Ethical Survey, metoda CAWI. Te badania objęły 59 dużych europejskich przedsiębiorstw.

W raporcie czytamy o trzech głównych elementach wpływajacych na budowanie etycznej organizacji: zdefiniowanie wartości, wdrożenie odpowiednich rozwiązań pozwalających rozwijać i chronić te wartości, w tym kanałów zgłaszania nieprawidłowości, oraz wdrożenie narzędzi monitoringu prowadzonych działań. Autorzy badania wskazują na trudność w precyzyjnym zdefiniowaniu, czym jest kultura etyczna. Jednakże podejmuja próbę wskazania jej dwóch kluczowych elementów. Jednym są wartości etyczne wyrażone w korporacyjnym kodeksie etycznym wspieranym przez program etyczny (czyli różnego rodzaju procedury, regulacje, ciała organizacyjne, systemy zarządzania, narzędzia, szkolenia, które definiują kulturę organizacji i tłumacza jak jako organizacja osiagamy cele i jakie postępowanie jest właściwe). Drugim jest zaangażowanie liderów organizacji, którzy przez swój przykład i działania promujące pożądane postawy wpływają na zachowania innych pracowników

33 Ibidem, s. 18-20.

${ }^{34}$ G. Donde, Corporate Ethics Policies and Programmes. 2016 UK and Continental Europe Survey, Institute of Business Ethics, London 2016. 
organizacji. Spośród uczestników badania $64 \%$ stwierdziło, że kadra zarządzająca najwyższego szczebla jest bardzo zaangażowana ${ }^{35} \mathrm{w}$ rozwijanie kultury etycznej w ich organizacjach. W $25 \%$ badanych firm zagadnienia etyczne sa poruszane podczas spotkań zarządu co najmniej raz na kwartał, w 14\% - co najmniej raz na pół roku, a w 33\% - co najmniej raz w roku. O ile badani wskazywali wsparcie i zaangażowanie zarządu w rozwijanie kultury etycznej, o tyle jedynie w 40\% przypadków stwierdzili, że pracownicy angażują się w działania na rzecz etyki ${ }^{36}$.

Jak wskazuja wyniki badania, 96\% analizowanych firm posiada spisane wartości. Wartości definiowane przez organizacje można podzielić na dwie grupy: wartości biznesowe (np. jakość obsługi klienta czy duch przedsiębiorczości) oraz na wartości etyczne (np. szacunek czy lojalność) ${ }^{37}$. Wartości biznesowe sa związane z tym, jakie sa cele komercyjne organizacji, natomiast wartości etyczne wskazuja, w jaki sposób te cele są osiagane. Z punktu widzenia edukacji menedżerskiej warto podkreślić, że zestaw wartości etycznych, jakimi kierują się organizacje, a zwłaszcza rozumienie tych wartości, co jakiśs czas się modyfikuje $-82 \%$ badanych firm zadeklarowało, że nastapiły zmiany $\mathrm{w}$ ich kodeksach etycznych ${ }^{38}$.

Autorzy omawianego badania również podjęli próbę odpowiedzi na pytanie, z jakimi wyzwaniami etycznymi najczęściej respondenci mają do czynienia. Ponad połowa odpowiadających jako główny problem etyczny wskazała korupcję i łapownictwo; 43\% zmaga się z jednym z elementów programów etycznych, czyli mechanizmami zgłaszania naruszeń, które albo nie są używane przez pracowników, albo w nieodpowiedni sposób. Dla 41\% wyzwaniem jest zapewnienie przestrzegania standardów etycznych $\mathrm{w}$ łańcuchu dostaw. $\mathrm{Na}$ kolejnych miejscach znalazły się: etyczne wątpliwości związane z wykorzystaniem dużych baz danych (ang. big data; 23\%), kwestie bezpieczeństwa i higieny pracy (21\%), zarządzanie konfliktem interesów (21\%), a także problem mobbingu, nękania i zastraszania ${ }^{39}$.

W 95\% badanych przedsiębiorstw w celu rozwoju kultury etycznej oraz minimalizowania powstawania nieetycznych zachowań wdrożono programy etyczne. We wszystkich firmach, które wdrożyły program etyczny, został opracowany kodeks etyki lub równorzędny dokument. W 93\% przypadków prowadzone są szkolenia dla pracowników. W takiej samej liczbie przypadków wdrożone zostały kanały zgłaszania nieprawidłowości. Inne elementy programu etycznego to wewnętrzne raportowanie o sposobie funkcjonowania programu etycznego czy zaangażowanie zewnętrznych interesariuszy $\mathrm{w}$ działania z zakresu etyki biznesu. Respondenci zapytani o cel opracowania kodeksu etycznego wskazali, że ma służyć on przede wszystkim jako: przewodnik dla pracowników (88\%), element budowania kultury korporacyjnej (81\%), publiczne zobowiązanie do przestrzegania standardów etycznych (61\%). Mniej badanych

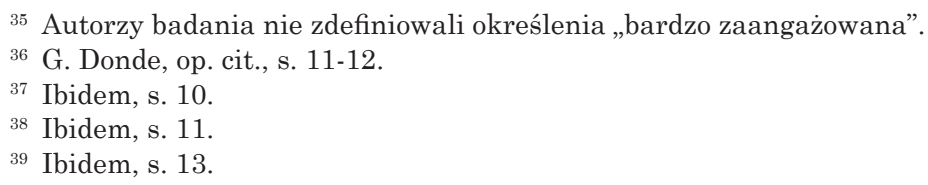


wskazało, że ma spełniać funkcję ochrony reputacji (27\%), zmniejszenia ryzyka operacyjnego (20\%) czy wskazywania wymagań etycznych dla dostawców i innych partnerów biznesowych $(20 \%)^{40}$.

Autorzy badania wskazali na kluczową rolę szkoleń w zakresie etyki biznesu, które mają budować świadomość etyczną, wspierać komunikację oraz pomóc pracownikom zrozumieć oczekiwania etyczne wobec nich stawiane przez pracodawcę. W 75\% badanych firm szkolenia w zakresie etyki biznesu są obowiązkowe dla wszystkich pracowników, a w 95\% przypadków taki obowiązek dotyczy kadry zarządzającej ${ }^{41}$.

Natomiast samo przeprowadzanie efektywnego szkolenia stanowi wyzwanie dla firm, o czym przekonuja autorzy badania przeprowadzonego przez organizacje Navex Global „2015 Ethics\&Compliance Training Benchmark Report” ${ }^{\prime 2}$. Szkolenia lub warsztaty dla pracowników na temat etyki stanowia ważny element budowania kultury etycznej. Szkolenie to jeden z niewielu momentów, w którym pracownicy mogą skoncentrować się na tym ważnym dla organizacji temacie.

Przyczyn niepowodzeń szkoleń z etyki biznesu najczęściej należy szukać poza samym szkoleniem. Jeśli praktyka firmy odstaje od treści przekazywanych na szkoleniu, to prowadzący szkolenie spotykają się z oporem wynikającym z cynizmu pracowników, zwłaszcza gdy celem szkolenia jest wypracowanie wartości, które mają wpłynąć na zmianę kultury organizacyjnej. Według wyników badań przedstawionych w omawianym raporcie (przeprowadzonych na próbie prawie 700 specjalistów zajmujących się w przedsiębiorstwach szkoleniami z etyki biznesu) cynizm pracowników stanowi główne źródło oporu (37\%). Cynizm wynika przede wszystkim z dwóch powodów. Pierwszy to negatywne doświadczenie braku wprowadzania zmian, których propozycje były w przeszłości konsultowane bądź wypracowywane z pracownikami. Drugi ma swoje źródło w zachowaniach kadry menedżerskiej, które nie są zgodne z deklarowanymi przez firmę wartościami. Według tych samych badań pracownicy nie biorą udziału w szczerych rozmowach na temat etyki w obawie przed odwetem ze strony pracodawcy (35\%). Wyniki badania wskazują kadrę menedżerską średniego szczebla jako tę grupę w hierarchii firmy, która negatywnie wpływa na budowanie kultury etycznej $\left(34 \%\right.$ odpowiedzi) ${ }^{43}$.

Hierarchia ważności celów i treści powinna być uzależniona od potrzeb organizacji. Warto podkreślić, że dominującym celem dla biorących udział w przywoływanym badaniu jest budowa etycznej, bardziej efektywnej kultury organizacyjnej (46\% wskazań). Na drugim miejscu znalazło się zapewnienie zgodności z prawem i regulacjami (31\% respondentów). Zdecydowanie niżej w hierarchii celów znajdują się: zapobieganie przyszłym ryzykom i niezgodnościom (7\%); wymagania audytowe (5\%) czy uczenie kultury otwartej rozmo-

\footnotetext{
40 Ibidem, s. 17.

${ }^{41}$ Ibidem, s. 28-30.

42 I. Fredeen, 2015 Ethics\&Compliance Training Benchmark Report, Navex Global, Lake Oswego 2016.

${ }^{43}$ Ibidem, s. 10.
} 
wy $(3 \%)^{44}$. A niska pozycja tego ostatniego jest szczególnie niepokojąca w kontekście obecnego deficytu umiejętności prowadzenia rozmów i artykułowania argumentów etycznych.

Niemal wszędzie na świecie, jak pokazują wyniki omawianego badania, osoby odpowiedzialne za organizację szkoleń z etyki napotykaja te same wyzwania: niewystarczajacca liczba godzin szkoleniowych (21\% odpowiedzi) czy brak możliwości podjęcia wszystkich ważnych tematów (14\% wskazań) ${ }^{45}$. Zatem edukacja prowadzona w przedsiębiorstwach w zakresie etyki biznesu nie jest w stanie zastapić wiedzy, która może być zdobyta w czasie nauki uniwersyteckiej.

\section{PODSUMOWANIE}

Współczesne badania dotyczace etyki biznesu w centrum uwagi stawiają zagadnienie korupcji i podejścia do zarządzania oraz doboru odpowiednich narządzi, które umożliwią budowanie etycznej kultury korporacyjnej. Aby jednak dotrzeć do źródeł nieetycznych zachowań, konieczne jest sięgnięcie do wiedzy filozoficznej, psychologicznej i socjologicznej, a nie tylko zarządczej. W tej pierwszej kategorii wiedzy odnajdziemy odpowiedź na pytania: dlaczego? oraz co? W tej drugiej - jak?

Jednakże - jak przekonuje Nussbaum - współcześni menedżerowie nie posiadają odpowiednich umiejętności ani warsztatu pozwalającego odpowiedzieć na fundamentalne pytanie o przyczyny nieetycznych zachowań. A brak ten wynika z marginalizowania perspektywy humanistycznej w edukacji.

Zaprezentowanie zarówno perspektywy humanistycznej, jak i zarządczej pozwala na przedstawienie listy wybranych tematów, jakie mogą być istotne w dydaktyce przyszłych menedżerów. Kryterium doboru tych zagadnień jest ich użyteczność po przejściu z etapu edukacji do etapu aktywności biznesowej absolwentów. Użyteczność rozumiana jako umiejętność tworzenia ładu zbiorowego oraz świadomość odpowiedzialności za dokonywanie zmiany. A perspektywa zarządzającego jako świadomego kreatora zamiany jest perspektywą dominująca w zarządzaniu humanistycznym.

Podsumowując, możemy wyróżnić zagadnienia istotne dla programu zajęć skierowanego do przyszłych zarządzających. Należą do nich: zwracanie uwagi na istotne czynniki kultury korporacyjnej i jej świadome kształtowanie w kierunku ponoszenia osobistej odpowiedzialności, unikania powodowania poczucia anonimowości i traktowania pracowników jako bezimiennych mas. Zachęcanie do krytycznej oceny sytuacji i promowanie postawy zgłaszania sprzeciwu. Wychowanie do roztropnego posługiwania się władzą.

Jak pokazują wyniki prezentowanych badań, nadal istnieje wyraźna konieczność mówienia o problemie korupcji, konfliktu interesów, przestrzegania praw człowieka, standardów BHP, a zwłaszcza praw pracowniczych i dbania

44 Ibidem, s. 7.

${ }^{45}$ Ibidem, s. 18. 
o dobre relacje wewnętrzne. Podkreślmy, że najczęstszymi problemami są te związane z komunikacją i niskim standardem relacji międzyludzkich: w 11 z 13 badanych krajów kłamstwo, szykanowanie i zastraszanie badani zakwalifikowali jako trzy najczęstsze przypadki nieetycznych zachowań.

O pilności i istotności poruszania wskazanych zagadnień w dydaktyce uniwersyteckiej przyszłych menedżerów świadczą prezentowane wyniki badań, z których wynika, że największej liczby nadużyć gospodarczych dopuszczaja się przedstawiciele tak zwanego pokolenia Y, czyli osoby w wieku 25-34 lata. A więc niedawni absolwenci szkół ekonomicznych i biznesowych.

dr Robert Sroka

Akademia Leona Koźmińskiego

Warszawa

rsroka@kozminski.edu.pl

SOME PROPOSALS OF TOPICAL ISSUES TO BE INCLUDED

\section{IN THE CURRICULUM OF MANAGERIAL STUDIES FOR FUTURE MANAGERS, SPECIALISTS IN BUSINESS ETHICS}

\section{Sum mary}

In this paper the most relevant and up-to-date topics that should be included in the curriculum of university programmes educating future managers have been proposed. The list of proposed topics was drafted based on: (i) the analysis of business phenomena conducted in the humanistic management approach based on the thoughts of Martha C. Nussbaum, and (ii) the conclusions arrived at in a recognised international research in business ethics carried out at an organisational level. 